http://jmscr.igmpublication.org/home/ ISSN (e)-2347-176x ISSN (p) 2455-0450

crossref DOI: https://dx.doi.org/10.18535/jmscr/v8i2.130

Journal Of Medical Science And Clinical Research

\title{
The Study of C- Reactive Protein in Acute Myocardial Infarction in Elderly
}

Authors

\section{Dr Bhagyamani ${ }^{1}$, Dr Kaushal Kishore ${ }^{2 *}$, Dr Abhay Kumar Sinha ${ }^{3}$}

${ }^{1}$ Junior Resident, Department of Medicine, Patna Medical College \& Hospital, Patna

${ }^{2}$ Professor, Department of Medicine, Patna Medical College \& Hospital, Patna

${ }^{3}$ Assistant Professor, Department of Medicine, Patna Medical College \& Hospital, Patna

*Corresponding Author

Dr Kaushal Kishore

Professor, Department of Medicine, Patna Medical College \& Hospital, Patna, India

\section{Abstract}

Acute Myocardial Infarction is one of the most common diagnosis in hospitalised patients. The most common cause of myocardial ischemia is atherosclerotic disease. In patients with acute myocardial infarction, elevated concentration of inflammatory markers are correlated with worse clinical outcome. Now- a-days attention has been focused on various novel inflammatory markers, especially C -reactive protein $(C R P)$.Our aim was the correlation of $C$ reactive protein in acute myocardial infarction, and determine its significance in prognosis.

Methods: Patients who have been diagnosed as acute myocardial infarction (ST Elevation Acute myocardial Infarction or Unstable angina/Non ST Elevation Myocardial Infarction) and admitted to Patna Medical College and Hospital were the subjects. Sample consisted of 60 cases of acute myocardial infarction. Patients more than 60 years were taken as subjects. Apart from routine blood investigations, serum cardiac biomarkers, electrocardiography and echocardiography was done in all patients. All patients were followed up and observed for the development of complications.

Results: Maximum incidence of acute coronary syndrome was observed in age group between 61 to 70 years. Out of 60 patients with acute myocardial infarction, 41 patients had STEMI and 19 patients had UA/NSTEMI. According to qualitative method of assay of $C$-reactive protein estimation, a level, equal to or more than $0.6 \mathrm{mg} / \mathrm{dL}$ is detected as positive. A level below $0.6 \mathrm{mg} / \mathrm{dL}$ is denoted as negative. In our study, among 60 patients $46(76 \%)$ patients had $C$ reactive protein levels positive(highly significant, $p<0.001)$ and $14(24 \%$.) had CRP value negative.

Conclusion: These findings suggest high CRP has positive correlation in patients with acute myocardial infarction. Raised Plasma CRP levels in majority of patients with AMI suggests involvement of inflammation in MI.

\section{Introduction}

ACS includes acute myocardial infarction with ST-segment elevation (STEMI) on their presenting electrocardiogram and those with nonST-segment elevation acute coronary syndrome (NSTE-ACS). The latter includes patients with
non-ST-segment elevation myocardial infarction (NSTEMI), which by definition, have evidence of myocyte necrosis, and those with unstable angina (UA) which do not have evidence of myocyte necrosis. ${ }^{1}$ The most common cause of myocardial ischemia is atherosclerotic disease of an epicardial 
coronary artery sufficient to cause a regional reduction in myocardial blood flow and inadequate perfusion of the myocardium supplied by the involved coronary artery ${ }^{2}$.

Now- a- days attention has been focused on various novel inflammatory markers, especially $\mathrm{C}$ reactive protein (CRP). CRP is not only marker of inflammation but also play an active role in atherogenesis $^{3}$. In clinical studies, it is shown that, circulating levels of CRP were found to correlate with total infarct size in acute myocardial infarction, and with prognosis. Thus, CRP is an indicator of underlying coronary inflammation as well as extent of myocardial necrosis.

To detect active inflammation and infection, CRP used to be measured using immunoturbidimetric or immunoelectrophoretic assays. The normal serum concentration of CRP is below $10 \mathrm{mg} / \mathrm{L}$. In the mid 1990s, immunoassays for C-reactive protein (CRP), with greater sensitivity than those previously in routine use, revealed that increased CRP values, even within the range previously considered normal, strongly predict future coronary events ${ }^{4}$. Because these ranges are not sensitive for the values required to determine cardiovascular risk in otherwise healthy persons, investigators have developed new, modified techniques to measure high-sensitivity CRP. The high-sensitivity CRP assay has been shown to detect concentrations below $1 \mathrm{mg} / \mathrm{L}(<1,1-3,>3$ $\mathrm{mg} / \mathrm{L}$ correspondes to low, moderate and high risk) and uses labelled monoclonal or polyclonal anti-CRP antibodies in an enzyme- linked immunosorbent assay (ELISA) or an immunofluorescent assay. The recent emphasis in cardiovascular medicine on "high-sensitivity" or "highly sensitive" CRP, abbreviated as so-called hs-CRP, seems to have created a false impression in some quarters that this is somehow a different analyte from "conventional" CRP. This is incorrect. The "high sensitivity" refers simply to the lower detection limit of the assay procedures being used. The actual CRP analyte, the plasma protein that is being measured, is the same regardless of the assay range. Very sensitive CRP assays have been reported from research laboratories for 30 years. The new development is the introduction of commercial and automated routine CRP immunoassay systems with greater sensitivity than before ${ }^{4}$.

\section{Methods}

Source of Data: Patients who have been diagnosed as acute myocardial infarction (ST Elevation Acute myocardial Infarction or Unstable angina/Non ST Elevation Myocardial Infarction) and admitted to Patna Medical College and Hospital were the subjects.

Sample Size: Sample consisted of 60 cases of acute myocardial infarction. Patients more than 60 years were taken in this study.

C-reactive Protein Assay: CRP assay was performed by rapid slide agglutination test for the direct detection and semiquantitation of C-reactive protein. The reagent is a latex particle suspension coated with specific antihuman C-reactive protein antibodies which agglutinates in the presence of CRP in serum of the patients. According to this method of assay of $\mathrm{C}$ reactive proteins estimation, a level, equal to or more than $0.6 \mathrm{mg} / \mathrm{dL}$ is detected as elevated level of CRP. A level below $0.6 \mathrm{mg} / \mathrm{dL}$ is denoted as normal concentration of CRP .

\section{Results}

Age Distribution: Maximum incidence of acute coronary syndrome was observed in age group between 61 to 70 years.

Distribution of acute myocardial infarction among different Age groups and sex

\begin{tabular}{|c|c|c|c|c|c|}
\hline Age Groups & \multicolumn{2}{|c|}{ STEMI } & \multicolumn{2}{c|}{ UA/NSTEMI } & \\
\cline { 2 - 6 } In years & Males & Females & Males & Females & Total \\
\hline $61-70$ & 18 & 7 & 8 & 4 & 37 \\
\hline $71-80$ & 10 & 6 & 6 & 1 & 23 \\
\hline Total & 28 & 13 & 14 & 5 & 60 \\
\hline
\end{tabular}

Sex Distribution: In this study of the 60 patients we observed, $42(70 \%)$ patients were males and $18(30 \%)$ female patients. There were (41)68\% STEMI patients; of these 28 were males and 13 females. And of 19 UA/NSTEMI, 14 were from male and 5 from female group. 


\section{Classification of Acute Myocardial infarction}

Out of 60 patients with acute myocardial infarction, 41 patients had STEMI and 19 patients had UA/NSTEMI. Types of ST elevation MI: Out of 41 patients who had STEMI, the distribution of lesions was as follows: Extensive anterior wall involvement was the most common type followed by inferior walls, Anteroseptal and Anterolateral.

$C$ reactive Protein Levels at admission: According to qualitative method of assay of $\mathrm{C}$ reactive protein estimation, a level, equal to or more than $0.6 \mathrm{mg} / \mathrm{dL}$ is detected as positive. A level below $0.6 \mathrm{mg} / \mathrm{dL}$ is denoted as negative. In our study, among 60 patients 46(76\%) patients had $\mathrm{C}$ reactive protein levels positive(highly significant, $\mathrm{p}<0.001)$ and $14(24 \%$.) had CRP value negative.

Table: 4. Distribution of CRP level

\begin{tabular}{|c|c|}
\hline C Reactive Protein Level & Total \\
\hline$<0.6 \mathrm{mg} / \mathrm{dl}$ & 14 \\
\hline$>0.6 \mathrm{mg} / \mathrm{dl}$ & 46 \\
\hline Total & 60 \\
\hline
\end{tabular}

Fig 1: Distribution of CRP

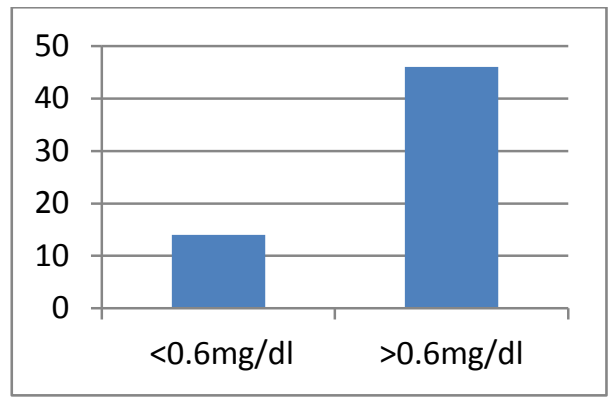

\section{Complications}

We have studied 60 patients. Out Of Which 46 (76\%) patients had raised CRP levels $(\geq$ $0.6 \mathrm{mg} / \mathrm{dl}) \quad(\mathrm{p}<0.001)$ out of which $28(60 \%)$ patients had complications and 18(40\%) patients had no complications and 14 (24\%) patients had CRP levels $(<0.6 \mathrm{mg} / \mathrm{dl})$ in which $5(36 \%)$ patients had complications and 9(64\%) Patients had no complications. Left ventricular failure was the most common complication seen, followed by Cardiogenic shock.

\section{Discussion}

There is high correlation between raised CRP level and acute myocardial infarction. In our study, among 60 patients $46(76 \%)$ patients had C reactive protein levels positive (highly significant, $\mathrm{p}<0.001)$ and $14(24 \%$.) had CRP value negative.

Out of $46(76 \%)$ patients had raised levels ( $\geq$ $0.6 \mathrm{mg} / \mathrm{dl}$ ) out of which 28 patients had complications and 18 patients had no complications and 14 (24\%) patients had CRP levels $(<0.6 \mathrm{mg} / \mathrm{dl})$ in which 5 patients had complications and 9 Patients had no complication. Foussas et al ${ }^{5}$ studied 1,846 patients with acute myocardial infarction and showed that, elevated plasma CRP levels confer a significantly increased risk of future fatal or non- fatal ischemic complications. Mohmoud Suleiman et $\mathrm{al}^{6}$ concluded that, plasma CRP levels obtained within 12-24 hours of symptom onset is an independent marker of 30- day mortality and the development of heart failure in patients with acute myocardial infarction. A K Shrivastav ${ }^{7}$ showed that CRP is believed to be both a marker and a mediator of atherosclerosis. Pietila $\mathrm{K} \mathrm{O}^{8}$ showed that, high serum CRP concentrations in acute myocardial infarction patients treated with thrombolytic drugs predict increased mortality up to 6 months following the myocardial infarction. Thus, we conclude that CRP is an independent prognostic indicator and is associated with more adverse events in patients with acute myocardial infarction.

\section{Conclusion}

Raised Plasma CRP levels in majority of patients with AMI suggests involvement of inflammation in MI. It is an important predictor of high risk in AMI patients and raised CRP levels are independent markers of adverse outcomes in acute myocardial infarction patients .

\section{References}

1. Robert P.Giugliano, Christopher P. Cannon, Eugene Braunwald, Harrisons Principles of internal medicine; $20^{\text {th }} \mathrm{Ed}$; 
New York: Mc Graw Hill 2018; p- 18661872.

2. Elliott M. Antman, Joseph Loscalzo , Harrisons Principles of internal medicine; $20^{\text {th }}$ Ed; New York: Mc Graw Hill 2018; p- 1850-1855

3. Ishikawa $T$, Hatakeyama $K$, Imamura $T$, Date $\mathrm{H}$, Shibata $\mathrm{Y}$, Hikichi $\mathrm{Y}$ et al. Involvement of C-reactive protein obtained by directional coronary atherectomy in plaque instability and developing restenosis in patients with stable or unstable angina pectoris. Am J Cardiol. 2003;91:287-92.

4. Mark B Pepys, G M Hirchfield,C-reactive protein:a critical update,the journal of Clinical Investigation,2003;111(12);18051812.

5. Foussas SG, Zairis MN, Lyras AG, Patsourakos NG, Tsirimpis VG, Katsaros $\mathrm{K}$ et al, Early prognostic usefulness of $\mathrm{C}$ reactive protein added to thrombolysis in myocardial infarction risk score in acute myocardial infarction, Am. J. Car, Aug 2005; 96; p533-537.

6. Suleiman M, Aronson D, Reisner SA, Kapeliovich MR, Markiewicz W, Levy Y et al, Admission $\mathrm{C}$ reactive protein levels and 30-day mortality in patients with acute myocardial infarction. Am Jr of Med; Dec 2003, 115; 9 p695-701.

7. A K Shrivastav ,C-reactive protein , Inflammation, CHD Egyptian Heart Journal, vol 67, 2015 ,page 89-97

8. Pietila KO, Harmonen AP, Jokinitty J, Pasternack AI, Serum C reactive protein concentration in acute myocardial infarction and its relationship to mortality during 24 months of follow-up in patients under thrombolytic treatment, Eur Heart J, 1996;17;p 1345-1349.
9. Nicola R Soroston, Jason J Ashworth, Role of CRP at site of inflammation and infection, Front Immunol , $2018 ; 9 ; 754$. 